\title{
Model Pembelajaran Learning Cycle (Lc) 7e Pada Pokok Bahasan Jamur
}

\author{
Hana Sumiati Widjaja hana.nbr13@gmail.com \\ SMA Kristen Anak Panah, Kabupaten Nabire
}

\begin{abstract}
This study was to study the influence of the 7E Learning Cycle (LC) model (obtain, involve, discuss, explain, discuss, discuss, expand, and understand), class 10 learning activities. The sampling method was carried out using saturated sampling techniques, the results showed thus the 7E Learning Cycle (LC) learning module can be used on the subject of mushrooms by looking at 3 aspects of values, namely cognitive, psychomotor and effective
\end{abstract}

Keyword: Learning Cycle 7E learning result, learning activity, fungi

\section{ABSTRAK}

Penelitian ini adalah untuk mempelajari pengaruh model 7E Learning Cycle (LC) (dapatkan, libatkan, diskusikan, jelaskan, diskusikan, diskusikan, perluas, dan pahami), kegiatan pembelajaran kelas 10. Metode pengambilan sampel dilakukan dengan menggunakan teknik sampling jenuh, Hasil menunjukkan bahwa modul pembelajaran Learning Cycle (LC) 7E dapat digunakan pada pokok bahasan jamur dengan melihat dari 3 aspk penilaian yaitu kognitif, psychomotoric dan efektif

Kata kunci: Learning Cycle 7E hasil belajar, aktivitas belajar, jamur

\section{PENDAHULUAN}

Guru dengan berbagai cara telah mengusahakan agar semua peserta didik aktif dalam kegiatan pembelajaran. Pembelajaran standar juga telah dilakukan oleh guru, berbagai media pembelajaran yang ada di sekolah telah dimanfaatkan, berbagai bentuk penugasan telah pula diberikan untuk dilaksanakan oleh peserta didik, baik di dalam maupun di luar kelas, mulai dari tugas melakukan observasi, melakukan eksperimen, membuat laporan singkat hasil eksperimen atau hasil observasi, mengerjakan LKS, dan lain sebagainya. Namun demikian, dalam berbagai kesempatan tanya jawab, diskusi kelas, praktikum maupun ulangan harian, prestasi belajar peserta didik baik dalam ranah kognitif, prikomotorik serta afektif sangat rendah. Aktivitas peserta didik dalam tanya jawab dan diskusi kelas masih rendah, hanya sekitar $40 \%$ peserta didik yang aktif. Sebagian besar dari peserta didik justru memperlihatkan aktivitas yang tidak relevan dengan pembelajaran, seperti kelihatan bengong dan melamun, kurang bergairah, kurang 
memperhatikan, bermain-main sendiri, berbicara dengan teman ketika dijelaskan, canggung berbicara atau berdialog dengan teman waktu diskusi, tidak mengerjakan tugas, ada beberapa peserta didik bermain HP pada waktu pembelajaran secara diam-diam, banyak peserta didik yang menguap ketika pembelajaran berlangsung dan lain sebagainya. Sementara itu dari hasil ulangan harian/ulangan blok, prestasi belajar peserta didik juga belum memuaskan. Nilai rata-rata hasil ulangan mata pelajaran biologi khususnya materi jamur belum mencapai 70 . Hanya sekitar $50 \%$ peserta didik yang mencapai KKM (65) dengan nilai rata-rata 60. hal terssebut mengindikasikan adanya permasalahan serius dalam kegiatan pembelajaran yang harus segera dicarikan pemecahannya. Kurikulum 2013 menetapkan prinsip pelaksanaan kurikulum didasarkan pada potensi, karakteristik, perkembangan dan kondisi peserta didik untuk menguasai kompetensi yang berguna bagi dirinya.

Menurut Trianto, 2007 hal 13 teori konstruktivis menyatakan bahwa peserta didik harus menemukan sendiri dan mentransformasikan informasi kompleks, mengecek informasi baru dengan aturan-aturan lama dan merevisinya apabila aturan-aturan itu tidak sesuai. Agar peserta didik benarbenar dapat memahami dan menerapkan pengetahuan, mereka harus bekerja memecahkan masalah, menemukan segala sesuatu untuk dirinya (Trianto 2007:13).

Ada beberapa model belajar yang dilandasi konstruktivisme, salah satunya adalah model learning cycle (siklus belajar) atau dalam penulisan ini disingkat LC, yang merupakan rangkaian tahap-tahap kegiatan (fase) yang diorganisasi sedemikian rupa sehingga pembelajaran dapat menguasai kompetensi-kompetensi yang harus dicapai dalam pembelajaran dengan jalan berperanan aktif. LC pada mulanya terdiri dari fase-fase eksplorasi (exploration), pengenalan konsep (concept introduction), dan aplikasi konsep (concept application) (Eisencraft, Arthur. 2003). LC tiga fase saat ini telah dikembangkan dan disempurnakan menjadi 5, 6 dan 7 fase. Berdasarkan tahapan-tahapan dalam metode pembelajaran bersiklus di atas, diharapkan peserta didik tidak hanya mendengar keterangan guru tetapi dapat berperan aktif untuk menggali dan mengkonstruksi pemahaman mereka terhadap konsep-konsep yang dipelajari. Dengan demikian pengetahuan yang terbentuk dapat lebih lama berada dalam pikirannya. 


\section{METODE PENELITIAN}

Desain penelitian ini mengunakan kategori true experimental design dengan jenis control group pre-test, post-test. Populasi dari penelitian ini adalah peserta didik kelas X SMA Kristen Anak Panah, Kabupaten Nabire. Jumlah anggota populasi pada penelitian ini adalah 62 peserta didik yang berasal dari 2 kelas yaitu kelas XA dengan jumlah peserta didik 31 sebagai kelas eksperimen dan kelas XB dengan jumlah peserta didik 31 sebagai kelas kontrol. Penelitian ini merupakan penelitian populasi dimana seluruh populasi menjadi sampel penelitian (Arikunto, 2012: 108). Teknik pengambilan sampel adalah teknik sampling jenuh. Pembagian kelas XA menjadi kelas eksperimen dan kelas XB menjadi kelas kontrol. Kelas eksperimen mendapatkan perlakuan yaitu berupa penerapan model pembelajaran LC 7E, sedamgkan kelas kontrol tidak mendapat perlakuan, dengan kata lain menggunakan mengunakan pembelajaran konvensional.

Analisis hasil belajar kognitif peserta didik yang digunakan meliputi $\mathrm{n}$-Gain untuk mengetahui peningkat-an hasil belajar peserta didik, uji normalitas, uji homogenitas, dan uji perbedaan dua rata-rata. Di samping itu juga penilaian hasil belajar afektif diperoleh dari hasil dan psikomotorik dari lembar observasi, dan diakhiri pemberian angket aktivitas belajar untuk mengetahui tanggapan peserta didik terhadap aktivitasnya selama kegiatan pembelajaran. Penelitian ini juga dilengkapi dengan data kualitatif berupa hasil wawancara dengan beberapa peserta didik yang mewakili peserta didik dengan hasil belajar (n-Gain) rendah, sedang dan tinggi.

\section{HASIL DAN PEMBAHASAN}

\section{Penilaian Kognitif}

Hasil analisis rata-rata $n$-Gain hasil belajar peserta didik setelah mengikuti pembelajaran secara keseluruhan (3 kali pertemuan, RPP1, RPP2, RPP3) baik pada kelas kontrol maupun kelas eksperimen mengalami peningkatan. Data dapat dilihat pada diagram Gambar 1 sebagai berikut:

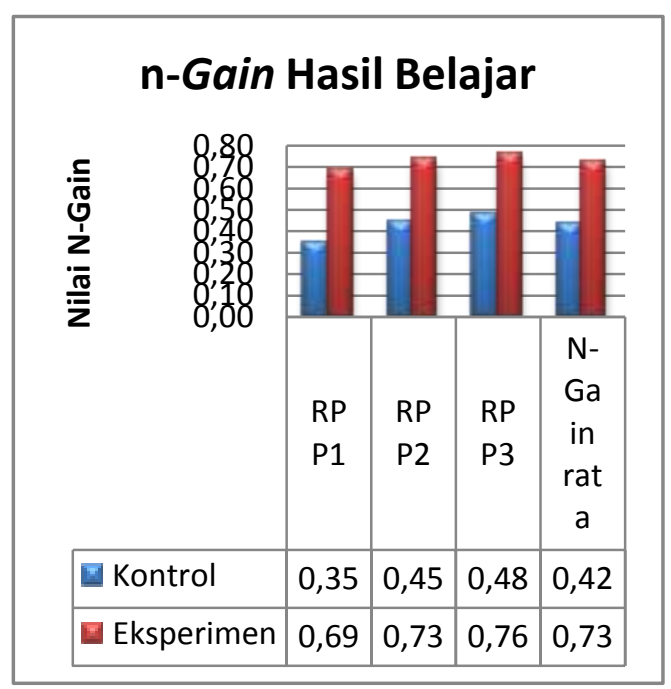

Gambar 1. Diagram n-Gain hasil belajar materi jamur dari tiga pertemuan 
Berdasarkan Gambar 1 menunjukkan bahwa RPP pertama dengan modul pembelajaran Learning Cycle $7 E$, peserta didik baru mengenal istilahistilah biologis pada jamur sehingga peningkatan hasil belajarnya tidak sebesar pada RPP kedua. Nilai n-Gain pada RPP ketiga baik pada kelas kontrol dan eksperimen merupakan nilai tertinggi dari dua pertemuan sebelumnya. Hal itu terjadi karena selain sudah familiar dengan istilah yang digunakan, juga karena materi pada pertemuan ketiga relatife lebih mudah yaitu manfaat jamur bagi kehidupan dan simbiosis jamur dari pada materi sebelumnya.

Kedua kelas mengalami peningkatan n-Gain pada setiap pertemuannya tetapi nilai $n$-Gain pada kelas eksperimen jauh lebih tinggi dari pada n-Gain kelas kontrol Gambar 2, sebagai berikut :

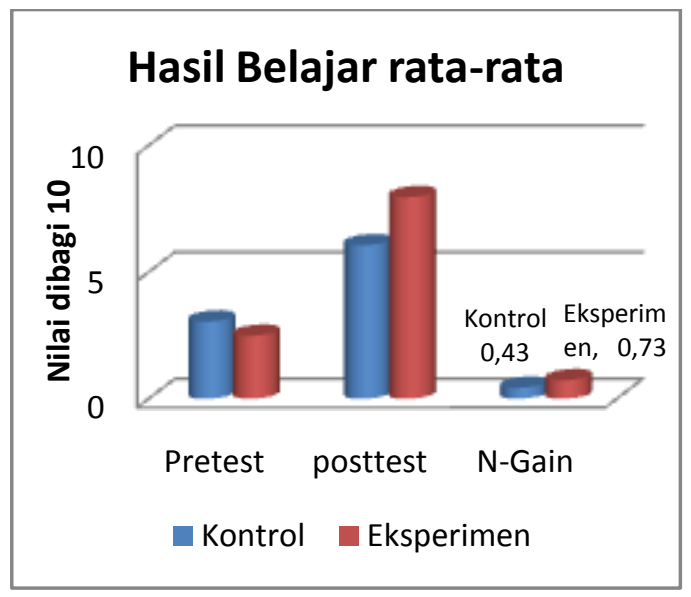

Gambar 2. Diagram batang n-Gain ratarata hasil belajar pada kelas kontrol dan eksperimen
Berdasarkan gambar 2 bahwa pada kelompok eksperimen diperoleh $n$-Gain rata-rata 0,73 termasuk kategori tinggi, sedangkan pada kelompok kontrol diperoleh $n$-Gain rata-rata 0,42 termasuk kategori sedang. n-Gain rata-rata hasil belajar pada kelompok eksperimen lebih tinggi dibandingkan kelompok kontrol.

Perbedaan tersebut didukung oleh hasil uji beda (uji-t) yang menunjukkan bahwa sig (2-tailed) $<0,05$, yang berarti bahwa $\mathrm{H}_{0}$ ditolak dan $\mathrm{H}_{1}$ diterima. Dengan diterimanya $\mathrm{H}_{1}$ berarti terdapat perbedaan peningkatan hasil belajar antara peserta didik pada kelompok kontrol dan kelompok eksperimen yang menerapkan metode LC 7E.

Hal tersebut sejalan dengan penelitian terdahulu yang dilakukan oleh Dwi Nur Apriani, dkk, pada tahun 2012 hal 4. Yang menggunakan model pembelajaran LC 7E dalam pelajaran kimia dapat menghasilkan ketuntasan belajar $94,59 \%$. Peningkatan ketuntasan belajar tersebut mengindikasikan adanya peningkatan hasil belajar dari peserta didik yang belajar dengan cara konvensional.

Model pembelajaran LC 7E mampu meningkatkan pemahaman terhadap materi yang dipelajari karena dipengaruhi oleh perkembangan proses mental yang terjadi selama belajar. Hal tersebut didukung oleh data yang sangat 
menarik pada gambar 2, bahwa nilai pretest pada kelas eksperimen lebih rendah daripada kelas kontrol. Hal tersebut menunjukan bahwa peserta didik pada kelas eksperimen bukanlah peserta didik yang lebih unggul / pintar daripada kelas kontrol. Tetapi setelah mengikuti proses pembelajaran dengan model LC 7E, peserta didik pada kelas eksperimen memiliki rata-rata nilai posttest yang lebih tinggi dari pada kelas kontrol. Itu disebabkan keseluruhan rangkaian kegiatan pembelajaran biologi dengan model LC 7E, sebagian besar proses pembelajaran dilaksanakan sendiri oleh peserta didik baik secara individual maupun kelompok. Oleh karena itu perkembangan mental peserta didik pada kelas eksperimen berkembang lebih baik, sehingga pemahaman konsepnya menjadi lebih baik juga. Model pembelajaran LC 7E sangat mendukung proses perkembangan mental pembelajar karena terdiri dari 7 tahapan pembelajaran yang berkesinambungan.

\section{Penilaian Psikomotorik}

Penilaian psikomotorik dilakukan pada setiap pertemuan tatap muka untuk mengetahui ketercapaian setiap aspek pembelajaran dari masing-masing pertemuan. Hasil penilaian psikomotorik rata-rata dari setiap pertemuan dapat dilihat pada Gambar 3 dan Gambar 4 sebagai berikut:

Aspek RPP2 kelas Eksperimen:

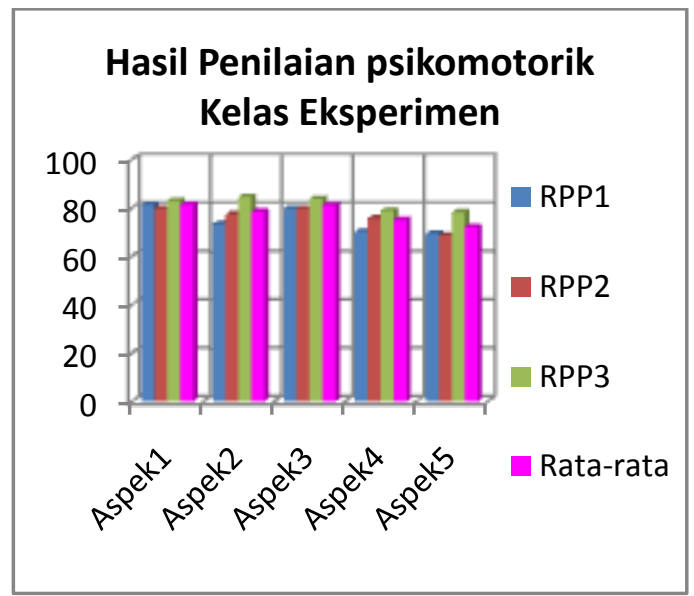

Gambar 3 Diagram batang rata-rata nilai psikomotorik masingmasing aspek pada kelas eksperimen

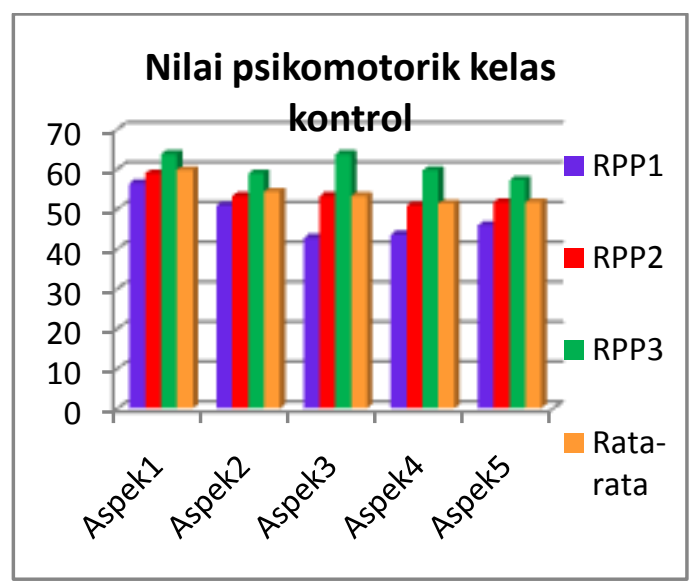

Gambar 4 Diagram batang rata-rata nilai psikomotorik masingmasing aspek pada kelas kontrol

Berdasarkan Gambar 3 dan 4 menunjukkan bahwa penilaian psikomotorik pada kelas eksperimen dan kelas kontrol memiliki aspek penilaian yang berbeda sehingga tidak bisa dibandingkan secara statistik. Dalam gambar 4 terlihat peningkatan nilai-nilai psikomotorik setiap aspek pada kelas 
kontrol dari RPP I ke RPP II dan RPP III. Hal tersebut menunjukkan bahwa semakin lama ketrampilan psikomotorik dari pertemuan ke-1 sampai pertemuan ke-3. Demikian pula pada kelas eksperimen (gambar 3.) hasil penilaian psikomotorik juga semakin meningkat dari pertemuan pertama sampai ke pertemuan ketiga.

Hal tersebut menunjukkan bahwa semakin terbiasa dengan metode pembelajarannya maka peserta didik akan semakin terampil secara psikomotorik.

Model pembelajaran LC 7E dapat mendorong peserta didik terlibat secara aktif dalam proses-proses sains seperti melakukan percobaan, menggunakan alat, mengamati, mengukur, mengumpulkan data, menyimpulkan dan sebagainya model pembelajaran LC 7E merupakan rangkaian tahap-tahap kegiatan (fase) yang diorganisasi sedemikian rupa sehingga pebelajar dapat menguasai kompetensikompetensi yang harus dicapai dalam pembelajaran dengan jalan berperanan aktif. Dalam pembelajaran ini, guru berperan sebagai fasilitator, pemandu, dan informan bagi peserta didik (Gunasih, 2011).

\section{Analisis Penilaian Affektif}

Penilaian affektif atau penilaian sikap dilakukan pada setiap pertemuan tatap muka untuk mengetahui ketercapaian setiap aspek sikap dalam seluruh kegiatan pembelajaran dari masing-masing pertemuan, baik selama diskusi, pratikum maupun presentasi ditunjukan Gambar 5 berikut:

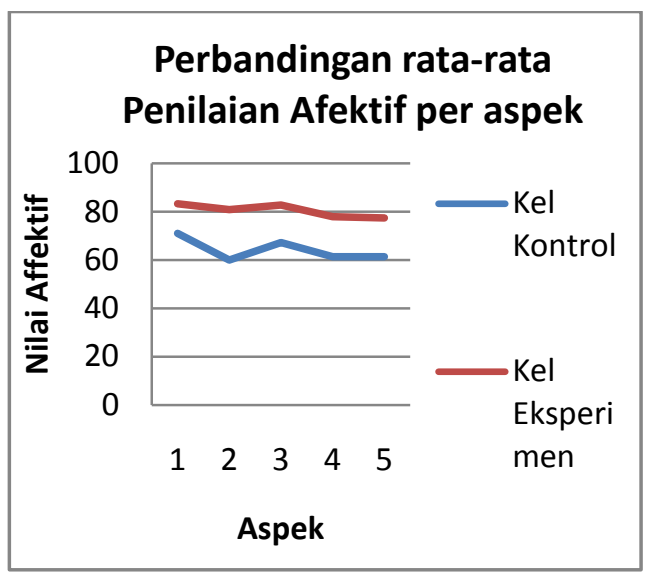

Gambar 5 Grafik perbandingan rata-rata nilai affektif masing-masing aspek pada kelas Kontrol dan eksperimen

Diagram garis pada Gambar 5. menunjukkan nilai hasil penilaian affektif rata-rata dari setiap aspek. Aspek penilaian affektif pada kelas eksperimen sama dengan aspek penilaian affektif kelas kontrol. Demikian pula dengan penilaian afektif pada kelompok eksperimen lebih tinggi daripada kelompok kontrol. Hal tersebut menunjukkan bahwa penggunaan metode LC 7E meningkatkan kemampuan afektif peserta didik. Hal tersebut membuktikan bahwa pembelajaran dengan model LC $7 \mathrm{E}$ dapat mendorong peserta didik terlibat secara aktif dalam proses-proses sains. 
Dengan demikian dapat menumbuhkan sikap-sikap positif dalam belajar.

Adapun yang melandasi pencapaian nilai affektif peserta didik kelas yang mengikuti LC 7E lebih baik dibandingkan kelompok konvensional karena secara teoritik jika dilihat dari filosofisnya, model LC 7E meletakkan dasar pada filosofis pendidikan yang menyatakan bahwa peserta didik akan belajar dengan baik apabila peserta didik diberi kesempatan untuk menemukan sendiri modul ini peserta didik dapat menemukan sendiri inquiri terbimbing dengan materi atau pokok bahasan yang mempelajari dengan benar (Siregar $\mathrm{T}$ dan Desri Natalia 2019 hal 8) Di samping itu, model LC 7E didasari pada motivasi intrinsik yang sesuai dengan faham konstruktivisme tentang pembelajaran, di mana peserta didiklah yang seharusnya mengalami pembelajaran. Peserta didik diajak selalu berpikir untuk menghadapi masalahmasalah dunia nyata yang berhubungan erat dengan materi pelajaran yang dibahas. Melalui proses berpikir ini diharapkan dapat menyelesaikan masalah-masalah yang dihadapinya sehingga dapat menghasilkan keputusan yang tepat.

\section{SIMPULAN.}

Modul pembelajaran Learning Cycle (LC) 7E dapat digunakan pada pokok bahasan jamur dengan melihat dari 3 aspek penilaian yaitu kognitif, psikomotorik dan effelatif.

\section{SARAN}

Modul pembelajaran Learning Cycle (LC) 7E diterapkan pada pokok bahasan jamur.

\section{DAFTAR PUSTAKA}

Arikunto, S. 2012. Dasar-Dasar Evaluasi Pendidikan. Jakarta: Bumi aksara.

Dwi Nur Apriani, Saptorini, dan Sri Nurhayati (2012). Pengaruh Pembelajaran Learning Cycle $7 e$ Terhadap Hasil Belajar Dan Keterampilan Generik Sains Peserta didik. http://journal.unnes.ac.id/sju/ind ex.php/chemined (on line) diunduh tanggal 30 Juni 2013

Eisencraft, Arthur. 2003. Expanding the 5E Model: A proposed 7E model emphasizes "transfer of learning" and the importance of eliciting prior understanding. (The National Science Teachers Association (NSTA)

Gunasih, N.L.A. 2011. Pengaruh Penerapan Model Pembelajaran Siklus Belajar Hipotesis Deduktif dengan seting 7E terhadap keterampilan berpikir kritis dan hasil belajar fisika peserta didik. Program Pascasarjana, Undiksha

Siregar T dan Desri Natalia 2019, Modul Pengembangan Inkuiri Terbimbing Pada Materi Larutan Elektrolit Non Elektrolit, Jurnal Ilmu Pendidikan Indonesia, 7(1), 8-16.

Trianto. 2007. Model-model Pembelajaran Inovatif Berorientasi Konstruktivistik. Jakarta: Prestasi Pustaka. 